\title{
Kutukan Sumber Daya Alam (Resource curse)
}

\section{Ahmad Sholikin}

\section{Abstrak}

Ada fenomena menarik yang oleh iluwan sosial disebut sebagai "kutukan sumber daya alam" (Auty 1993). Negara-negara yang berkelimpahan dengan sumber daya alam seperti minyak dan gas, performa pembangunan ekonomi dan tata kelola pemerintahannya (good governance) kerap lebih buruk dibandingkan negara-negara yang sumberdaya alamnya lebih kecil. Sebagai ironi, kebanyakan Negara yang berkembang sebagai pengekspor sumber daya alam cenderung memiliki kualitas hidup yang rendah. Untuk menambahkan lebih banyak paradoks, pemerintah kaya sumber daya alam cenderung memiliki kinerja yang lebih buruk dalam pembangunan politik daripada yang lainnya. Fenomena ini juga dikenal sebagai "paradox of plenty" dan dikutip dalam banyak literatur penelitian sebagai kutukan sumber daya alam.

Keyword : Sumber Daya Alam, Kutukan, Demokrasi

Sebelum akhir 1980-an, banyak peneliti-peneliti konvensional memiliki asumsi bahwa hubungan antara kelimpahan sumber daya alam dan pengembangan sebuah negara adalah saling menguntungkan untuk keduanya. Pada tahun 1950, misalnya Norton Ginsburg menyatakan bahwa: 'The possession of a sizable and diversified natural resource endowment is a major advantage to any country embarking upon a period of rapid economic growth' (Higgins 1968: 222). Pandangan serupa juga diungkapkan oleh ekonom arus utama selama periode ini (Viner 1952 dan Lewis 1955). Pada tahun 1960, teori Walter Rostow (1961) melangkah lebih jauh dengan alasan bahwa anugerah sumber daya alam akan memungkinkan negara-negara berkembang untuk membuat transisi dari keterbelakangan kepada industri 'take-off', seperti yang dilakukan oleh negaranegara seperti Australia, Amerika Serikat, dan Inggris. Periode selanjutnya ekonom neoliberal seperti P. J. Drake (1972), Bela Balassa (1980), dan Anne Krueger (1980) mengemukakan argumen yang sama, dengan alasan bahwa sumber daya alam bisa memfasilitasi pembangunan industri suatu negara dengan menyediakan pasar domestik dan dana yang diinvestasikan (1980: 2).

Secara paradoks, meskipun muncul harapan besar akan munculnya kekayaan dan luasnya peluang yang mengiringi temuan dan ekstraksi minyak serta sumberdaya alam lainnya, anugerah seperti itu kerap kali menjadi penghambat daripada menciptakan pembangunan yang stabil dan berkelanjutan. Di sisi lain, kekurangan sumberdaya alam ternyata belum terbukti menjadi penghalang terhadap kesuksesan ekonomi. Contohnya bintangbintang dari dunia berkembang, yakni Macan Asia (Hong Kong, Korea, Singapura, dan Taiwan) semuanya sukses memiliki industri ekspor yang maju berbasiskan barang-barang 
manufaktur dan pertumbuhan ekonomi yang pesat, padahal tidak memiliki cadangan sumberdaya alam besar.

Sejak akhir 1980-an, telah muncul literatur ilmiah yang cukup besar yang telah menantang kebijakan konvensional ini. Sejumlah ekonom radikal menantang pandangan ini sebelum akhir 1980-an, dengan alasan bahwa struktur ekonomi global dan sifat pasar komoditas internasional menempatkan negara-negara berkembang bergantung pada ekspor sumber daya alam pada kerugian yang serius (Singer 1950; Prebisch 1950). Gagasan bahwa sumber daya alam berpengaruh buruk bagi perkembangan pembangunan sebuah negara telah berkembang dan diterima secara luas oleh para peneliti dan pejabat dilembaga-lembaga keuangan internasional, Bank Dunia dan Dana Moneter Internasional (Bannon and Collier 2003; Sala-i-Martin and Subramanian 2003; Davis et al. 2003; Leite and Weidmann 1999; Sarraf and Jiwanji 2001: Isham et al. 2002; Eifert et al. 2003), serta oleh banyak Lembaga Swadaya Masyarakat (lihat misalnya, Save the Children 2003; Oxfam 2002). Literatur-literatur tersebut bisa dibilang kebalikan dari apa yang dipublish pada periode sebelum akhir 1980-an. Daripada dianggap sebagai berkat, literatur ini menyarankan bahwa melimpahnya sumber daya alam (atau setidaknya kelimpahan jenis tertentu dari sumber daya alam) meningkatkan kemungkinan bahwa negara-negara akan mengalami hasil ekonomi, politik dan sosial yang negatif termasuk kinerja ekonomi yang buruk, rendahnya tingkat demokrasi, dan perang saudara.

Di sisi lain, banyak negara kaya sumberdaya alam justru masih berjuang supaya bisa lepas landas dan mengejar pertumbuhan ekonomi yang mandiri. Bahkan ada di antaranya yang terjerembab ke dalam krisis ekonomi yang parah (Sachs and Warner 1995). Di sejumlah negara, sumberdaya alam memang telah membantu meningkatkan standar kehidupan, tapi sekaligus gagal menciptakan pertumbuhan yang mandiri. Selama kuartal terakhir abad kedua puluh, kendali atas atribut struktural telah menyebabkan pertumbuhan negara-negara kaya sumberdaya alam lebih lambat daripada pertumbuhan negara-negara miskin sumberdaya alam. Di samping kegagalan mencapai pertumbuhan ideal ini, ada pula keterkaitan erat antara kekayaan sumber alam dengan kemungkinan lemahnya perkembangan demokrasi (Ross 2001), korupsi (Salai-Martin and Subramanian 2003), dan perang saudara (Humphreys 2005).

Literatur tentang kutukan sumber daya alam terdiri dari tiga sub-literatur yang terpisah; Pertama, hubungan antara sumber daya alam dan kinerja ekonomi; Kedua, hubungan antara sumber daya alam dan rezim politik; dan Ketiga, hubungan antara sumber daya alam dan perang saudara. Gagasan kutukan sumber daya alam awalnya dikaitkan dengan sub-literatur yang pertama, karena kemunculannya jauh sebelum para peneliti lain mempublish hasil penelitiannya (lihat Ross 1999). Tetapi seperti dua sub-literatur lain yang telah muncul dan berkembang, yang kedua dalam menanggapi Wantchekon (1999) dan Ross (2001) 
dan yang ketiga dalam menanggapi studi seperti Collier dan Hoeffler (1998), kutukan sumber daya alam telah dipandang sebagai fenomena multi-dimensi, yang melibatkan tidak hanya kinerja pembangunan ekonomi, tetapi juga perang sipil dan otoritarianisme.

Titik kedua adalah bahwa istilah "sumber daya alam" didefinisikan bervariasi diseluruh literatur. Beberapa peneliti telah menetapkan istilah ini dalam hal komoditas tertentu, misalnya ; minyak, mineral, sumber daya hutan, dan tanaman pertanian. Disisi lain "sumber daya alam" didefinisikan dalam hal kepemilikan lahan atau ukuran sektor primer. Pada saat yang sama, ada beberapa perbedaan antara beberapa peneliti dalam kelompok pertama tentang beberapa komoditas yang dapat dianggap sumber daya alam, misalnya, termasuk tanaman pertanian sementara yang lainnya tidak. Ini tidak akan menjadi fokus perhatian dalam kajian literature ini, saya hanya membedakan antara studi yang meneliti efek perkembangan sumber daya alam secara umum dan orang-orang yang meneliti efek perkembangan sumber daya tertentu, misalnya minyak atau mineral.

Seperti disebutkan diatas, literatur tentang kutukan sumber daya alam telah mengajukan bukti yang cukup untuk menunjukkan bahwa sumber daya alam memiliki pengaruh yang buruk bagi pembangunan.

\section{Kinerja Ekonomi (Economic Performance)}

Sebagian besar penelitian telah menyajikan bukti yang menunjukkan bahwa melimpahnya sumber daya alam, atau setidaknya sumber daya alam tertentu dapat berdampak negatif terhadap pertumbuhan ekonomi. Wheeler (1984), menemukan bahwa di Afrika sub-Sahara, negara-negara yang kaya akan mineral memiliki pertumbuhan ekonomi yang lebih lambat dari mereka yang tidak kaya mineral selama tahun 1970-an. Demikian pula Gelb dan Associates (1988) menemukan bahwa Negara yang pertumbuhan ekonomi bertumpu pada sektor sumber daya alam mineral mengalami kerusakan yang serius, dalam hal efisiensi pembentukan modal dalam negeri selama periode 1971-1983. Hal ini mengarah kepada pertumbuhan ekonomi yang negatif pada Negara yang kaya sumber daya alam mineral, dan ini secara dramatis dapat menghambat pertumbuhan ekonomi Negara pengekspor minyak (lihat juga Auty 1993).

Sachs dan Warner (1995) meneliti satu set data yang besar dan beragam dari Negara-negara yang pertumbuhan ekonominya berdasarkan sumber daya alam antara tahun 1970 dan 1989 dengan hasil temuan bahwa sumber daya alam yang berlimpah memiliki korelasi negatif terhadap pertumbuhan ekonomi sebuah negara. Leite dan Weidmann (1999) dan Gylfason et al. (1999) mempublish hasil yang sama, juga dengan menggunakan set data yang besar. Auty (2001) menemukan bahwa pendapatan per kapita negara miskin sumber daya alam tumbuh lebih besar dua sampai tiga kali lipat dari negara yang memiliki sumber daya alam berlimpah antara tahun 1960 dan 1990. Mereka menemukan bahwa 
pertumbuhan ekonomi di Negara yang berbasis sumber daya alam cenderung memiliki pertumbuhan ekonomi yang rendah. Salah satu model gangguan ekonomi terkenal dari kutukan sumber daya alam adalah "dutch disease", sebuah fenomena penurunan di sektor manufaktur di Belanda setelah ditemukannya kantong gas alam besar di Groningen pada akhir tahun 1950-an.

Di bawah model gangguan ekonomi, ada beberapa gejala kutukan sumber daya alam, yaitu "dutch disease", ketidakseimbangan dalam sektor ekonomi dan "entrepreneurs rent-seeking" atau disinsentif terhadap kewiraswastaan. Dutch disease adalah ketika booming di sektor sumber daya alam menciptakan kontraksi di sektor ekonomi lain, terutama manufaktur dan sektor pertanian (Hausmann dan Rigobon 2002: 4; Davis 1995: 1768). Melalui mekanisme harga relatif, ekspor sumber daya alam membawa sejumlah besar mata uang asing yang menghargai pertukaran mata uang nilai. Selanjutnya, ia meningkatkan pendapatan riil dan perubahan domestik harga (Kolstad dan Wiig 2008: 2; Davis 1995: 1768). Kenaikan upah mendorong permintaan barang-barang yang tidak diperdagangkan dan menarik sumber daya ekonomi sektor tradable.

Pada saat yang sama, meningkatkan investasi di sektor nontraded, sehingga menurunkan produktivitas manufaktur dan pertanian (Torvik 2009: 251; Tadjoeddin 2007: 6). Dalam jangka panjang, de-industrialisasi dan deagriculturalization melemahkan industri "learning by doing" dan membuat produk sektor perdagangan yang diekspor tidak kompetitif di pasar internasional (Krugman, seperti dikutip Davis 1995: 1769). Selain itu, booming di sektor pemerintahan juga mungkin terjadi di bawah gejala "dutch disease" (Davis 1995: 1769). Di sisi lain, pengusaha rent seeking dan ketidakseimbangan sektor ekonomi pada dasarnya adalah hasil insentif dari harga sewa yang sangat potensial ditawarkan oleh kegiatan ekonomi sumber daya alam (Baland dan Francois 2000). Sumber daya alam membuat pengusaha enggan terlibat lebih jauh kegiatan ekonomi produktif; maka akan ada realokasi keterampilan dan sumber daya terhadap kegiatan ekstraksi sumber daya alam (Baland dan Francois, seperti dikutip Tadjoeddin 2007).

Peneliti lain telah menyajikan bukti yang menunjukkan bahwa masalah ekonomi di negara-negara yang memiliki sumber daya alam melimpah telah melampaui tingkat kemiskinan di Negara dengan sumber daya alam yang rendah. Nankani (1979), misalnya, menemukan bahwa pertumbuhan ekonomi negara yang kaya mineral disertai dengan dampak yang relatif buruk dalam hal; pertumbuhan pertanian, diversifikasi ekspor, dan inflasi. Sedangkan Negara dengan sumber daya alam mineral yang rendah memiliki dampak yang cenderung lebih ringan, seperti ditandai dengan jumlah tabungan yang buruk, dualisme upah, pengangguran yang tinggi, utang eksternal yang tinggi, dan pendapatan ekspor yang tidak stabil.

Wood dan Berge (1997) menemukan negara dengan sumber daya alam 
yang melimpah kurang memungkinkan untuk mengekspor barang-barang manufaktur daripada negara-negara yang miskin sumber daya alam. Leite dan Weidmann (1999) menemukan bahwa kelimpahan sumber daya alam cenderung diikuti oleh perilaku korupsi dari para pejabatnya. Atkinson dan Hamilton (2003) menemukan bahwa tingkat rata-rata tabungan di negara-negara yang berlimpah sumber daya alam lebih rendah daripada di negara-negara yang miskin sumber daya alam. Akhirnya, Ross (2003) menemukan bahwa di negara yang memiliki kekayaan minyak dan mineral melimpah tidak berdampak apapun bagi kehidupan orang miskin, khususnya dalam hal kemiskinan dan tingkat pembangunan manusia.

\section{Tipe Rezim (Regime Type)}

Literatur terkait kutukan sumber daya alam juga berisi sejumlah studi yang menunjukkan bahwa negara dengan sumber daya alam yang berlimpah dikaitkan dengan rendahnya tingkat demokrasi. Penelitian dari Arezki dan Ploeg 2008 menyoroti efek ketergantungan sumber daya ekonomi politik suatu negara dengan masuknya faktor kelembagaan. Ross (2001: 328) menemukan bahwa sumber daya alam menginduksi sistem politik yang kurang demokratis. Wantchekon (1999) misalnya, meneliti di 141 negara antara tahun 1950 hingga 1990 dan menemukan bahwa satu persen peningkatan ketergantungan sumber daya alam, yang diukur dengan rasio ekspor utama untuk PDB, meningkatkan probabilitas pemerintahan otoriter hampir 8 persen. Dia juga menemukan bahwa negara-negara yang kaya sumber daya alam lebih mungkin untuk mengalami transisi gagal atau lambat untuk demokrasi.

Sumbangan sumber daya alam memberi banyak kesempatan kepada pemerintah, seperti meningkatkan belanja publik, menurunkan tingkat perpajakan, meningkatkan aset keuangan pemerintah, sumber modal kerja untuk dipinjamkan kepada sektor swasta, dan sebagai sumber pembayaran utang pemerintah (Collier et.al 2009: 20). Namun, ketergantungan pada sumber daya alam anugerah dapat membahayakan kualitas pemerintahan dan demokrasi di suatu negara (Ross 2001; Haber dan Menaldo 2010). Pemerintah kaya sumber daya, dengan lebih besar sumber pendapatan dari sumber daya alam-sewa cenderung memberlakukan tingkat rendah pajak kepada rakyat. Karena itu, dalam artian 'tidak ada representasi tanpa perpajakan '(Luciani 1987: 75), akan ada sedikit permintaan untuk memegang pemerintahan untuk account, yang pada gilirannya membuat kaya sumber daya pemerintah menjadi kurang peka terhadap kebutuhan rakyat (Huntington 1991: 65).

Ross (2001) menemukan bahwa sumber daya alam mendorong bangkitnya sistem politik otoriter. Itu kemungkinan munculnya sistem patronase juga tinggi seperti yang dimiliki pemerintah sumber daya alam yang tidak diterima sebagai sumber untuk membayar dukungan (Caselli dan Cunningham 2009: 643; Kolstad dan Wiig 2008: 3). Tingkat rendah pajak juga merupakan bentuk lain dari sistem 
politik patronase dimana pemerintah mencoba mendapatkan beberapa popularitas (ibid). Namun, disisi lain, ada juga kemungkinan oposisi yang lebih besar untuk menantang kekuatan pemerintah (Caselli dan Cunningham 2009: 630).

Jensen dan Wantchekon (2004) menyajikan temuan yang serupa dalam kaitannya dengan Afrika, ia menyimpulkan bahwa negara dengan sumber daya alam yang melimpah di wilayah ini lebih cenderung menjadi otoriter, dan memiliki pengalaman kerusakan demokrasi setelah masa transisi. Ross (2001) menyelidiki apakah ada variasi dalam perihal rezim di berbagai jenis ekonomi sumber daya alam di berbagai daerah. Setelah memeriksa data dari 113 negara antara tahun 1971 dan 1997, ia menyimpulkan bahwa 'a state's reliance on oil or mineral exports tends to make it less democratic; that this effect is not caused by other types of primary exports; that it is not limited to the Arabian peninsula, to the Middle East, or to sub-Saharan Africa; and that it is not limited to small states'.

\section{Perang Saudara (Civil War)}

Sejumlah literatur menunjukkan bahwa Negara dengan sumber daya alam yang melimpah dikaitkan dengan timbulnya perang saudara, serta mempengaruhi durasi dan intensitas perang sipil. Setelah memeriksa pengalaman 98 negara dan 27 perang sipil, Collier dan Hoeffler (1998) menemukan bahwa sumber daya alam yang melimpah didefinisikan dalam hal rasio ekspor utama untuk PDB, dan menjadi penentu kuat dan signifikan dari perang sipil. Walaupun disisi lain ditemukan bahwa hubungan antara variabel-variabel tersebut kurang signifikan; pada awalnya kekayaan sumber daya alam akan meningkatkan risiko perang saudara tetapi setelah tingkat ekspor tertentu akan mengurangi risiko tersebut. Dalam sebuah studi berikutnya, mereka mengkonfirmasi temuan ini menggunakan set data yang lebih baik (Collier dan Hoeffler 2000). Dalam sebuah penelitian ketiga, mereka meneliti efek dari sumber daya alam yang berlimpah pada berbagai jenis perang saudara. Mereka menemukan bahwa sumber daya alam meningkatkan risiko perang saudara baik separatis dan non separatis, tetapi terjadi kecenderungan perang saudara tersebut terjadi tiga kali lebih besar terkait dengan sumber daya alam daripada penyebab lainnya (Collier dan Hoeffler 2002).

Reynal-Querol (2002) melakukan penelitian serupadengan fokus penelitian hubungan antara sumber daya alam dan timbulnya perang sipil baik etnis dan non-etnis. Menggunakan data dari sampel 138 negara antara tahun 1960 dan 1995, ia menemukan bahwa Negara dengan sumber daya alam yang berlimpah merupakan variabel penting dalam menjelaskan kejadian perang sipil non-etnis dan bentuk-bentuk kekerasan politik.

Tulisan terbaru Collier dan Hoeffler (2005) menunjukkan bahwa kekayaan sumber daya alam terus menunjukkan hubungan yang linear dengan timbulnya perang saudara, bahkan jika diukur berdasarkan sewa dari sumber daya alam yang 
melimpah diganti dengan produk ekspor asli mereka. Namun, mereka mencatat bahwa hasil ini kurang signifikan dibandingkan temuan mereka sebelumnya. Ukuran berbasis sewa di Negara yang memiliki sumber daya alam berlimpah menjadi tidak signifikan. Beberapa peneliti juga berkesimpulan bahwa Negara dengan sumber daya alam yang melimpah dapat memperpanjang durasi terjadinya perang saudara. Doyle dan Sambanis (2000) menemukan bahwa kekayaan sumber daya alam secara signifikan dan berkorelasi negatif dengan keberhasilan inisiatif perdamaian.

Ross (2004: 341) telah mencatat bahwa ada hubungan antara kegagalan inisiatif perdamaian dengan durasi perang saudara, temuan ini menunjukkan bahwa kekayaan sumber daya alam dikaitkan dengan perang saudara. Fearon (2004) menemukan bahwa negara-negara yang kaya akan sumber daya selundupan seperti opium, berlian, atau coca cenderung mengalami perang sipil. Akhirnya, Ross (2004: 45) mencatat, "several observers of Africa's civil wars, have suggested that natural resources worsen the intensity of civil wars 'by causing combatants to fight for territory that would otherwise have little value". Ross (2004) sendiri menemukan dukungan yang lemah untuk ide ini: dari tiga belas kasus perang saudara yang diperiksa, sumber daya alam hanya dengan jelas meningkatkan intensitas konflik dalam dua kasus; di sebelas orang lain, sumber daya alam tidak berpengaruh pada intensitas perang sipil.

Bukti menunjukkan bahwa kepemilikan sumber daya alam bisa menjadi kerugian bagi negara yang menguasainya. Belakangan, fenomena ini ditangkap dalam banyak penelitian dan teori dikembangkan untuk menjelaskan sifat 'kutukan sumber daya'. Secara umum, 'kutukan sumber daya alam' didefinisikan sebagai kumpulan hasil negatif yang berasal dari kepemilikan sumber daya alam. Teori utama dari kutukan sumber daya alam adalah bahwa hasil sosio-ekonomi negatif tidak berasal dari sumber daya alam itu sendiri, namun dari hasil ekstraksi sumber daya alam. Selain itu, meski tidak ada hubungan linier antara jumlah sumber daya alam diekstraksi dan hasil perkembangan negatif, efek berbahaya dari kutukan dapat meningkat karena ketergantungan pada sumber daya-sewa meningkat (Sala-iMartin dan Subramanian 2003: 11; Isham et al., 2005).

Pemetaan literatur terkait "kutukan sumber daya alam" terbagi kedalam dua arus besar; pandangan pertama, sebagian literatur memberikan bukti bahwa kelimpahan sumber daya alam dikaitkan dengan berbagai hasil pembangunan yang negatif, tetapi bukti ini tidak berarti konklusif. Gagasan tentang kutukan sumber daya tidak berarti konklusif, hal ini terjadi karena; (i) ada berbagai faktor yang berhubungan dengan pengukuran variabel kunci, terutama terkait dengan sumber daya alam yang berlimpah dan perang sipil. Hasil dari pengujian hipotesis antara perang sipil dan kepemilikan sumber daya alam semakin meningkatkan keraguan akan hipotesis kutukan sumber daya. (ii) tidak jelas apakah kutukan sumber daya alam dengan berbagai dimensinya berlaku untuk semua negara yang 
memiliki sumber daya alam atau hanya negara tertentu saja. Studi yang berbeda menunjukkan arah yang berbeda tentang masalah ini. Juga ada perdebatan di antara mereka yang berpendapat bahwa khususnya sumber daya alam adalah masalah utama yang paling merusak, jika dikaitkan dengan perang saudara. (iii) beberapa studi melaporkan temuan bertentangan dengan hipotesis kutukan sumber daya alam, bahkan ketika mereka menggunakan ukuran yang sama untuk mendukung hipotesis ini (seperti misalnya, dengan beberapa studi tentang hubungan antara sumber daya alam yang berlipah dan durasi perang saudara). (iv) studi ini tidak menggambarkan secara meyakinkan terkait arah sebab-akibat dari kekayaan sumber daya alam dan hasil-hasil pembangunan yang buruk, daripada sebaliknya menanyakan terkait pengaruh variabel ketiga yang independen.

Pandangan kedua, penjelasan yang ada terkait kutukan sumber daya alam tidak cukup untuk menjelaskan peran kekuatan sosial atau lingkungan ekonomi dan politik eksternal dalam membentuk hasil-hasil pembangunan di negara-negara yang memiliki sumber daya berlimpah. Sementara ada beberapa negara yang memiliki sumber daya berlimpah, memiliki tingkat perkembangan ekonomi yang cenderung membaik, beberapa contoh negara seperti Botswana, Indonesia, Chili, Norwegia, Australia, Kanada, dan Malaysia (Stevens 2003: 8).

Akhirnya berdasarkan studi di atas dapat menjadi bukti bahwa kelimpahan sumber daya alam atau setidaknya kelimpahan jenis tertentu dari sumber daya alam memiliki korelasi dengan berbagai hasil pembangunan. Secara umum masalah dasar dalam literatur "kutukan sumber daya alam" adalah bahwa sebagian besar peneliti telah tereduksionis kedalam pendekatan yang sama, mereka menjelaskan kinerja pembangunan semata-mata dari segi ukuran dan sifat dukungan sumber daya alam tersebut. Sebuah konsensus muncul bahwa berbagai variabel sosial dan politik memediasi hubungan antara kekayaan sumber daya alam dan hasil pembangunan, tetapi para peneliti cenderung melihatnya ditentukan oleh kepemilikan sumber daya alam.

Daripada bertanya mengapa kekayaan sumber daya alam mendorong terjadinya patologi politik yang menyebabkan kinerja pembangunan buruk, mereka seharusnya menanyakan faktor-faktor sosial dan politik yang memungkinkan beberapa negara dengan sumber daya alam melimpah untuk pembangunan negaranya (Schrank 2004; Snyder dan Bhavnani 2005).

Keterbatasan tersebut membuat penelitian ini memberikan perhatian yang lebih besar pertanyaan terakhir, bukan hanya karena akan meningkatkan pemahaman kita tentang kapan Negara dengan sumber daya alam yang berlimpah dikaitkan dengan hasil-hasil pembangunan, tetapi juga akan menghasilkan rekomendasi kebijakan yang berguna untuk mengatasi kutukan sumber daya alam.

Mereka berdebat terkait dukungan terhadap gagasan kutukan sumber daya alam berdasarkan kausalitas dari bukti korelasi. Namun, arah sebab-akibat 
mungkin sebenarnya adalah cara lain. Hal ini bisa saja perang sipil menyebabkan ketergantungan ekonomi pada sektor sumber daya alam, dengan asumsi bahwa akan membuat sulit bagi negara-negara untuk menarik investasi manufaktur. Schrank (2004) mengatakan bahwa, natural resource dependence may be a symptom of underdevelopment rather than the cause. Atau, hubungan antara ketergantungan sumber daya alam dan berbagai hasil pembangunan mungkin sama sekali tidak berkorelasi, hal ini mungkin hanya mencerminkan pengaruh variabel ketiga yang belum diketahui.

Sama seperti penjualan es krim dan jumlah kasus tersengat matahari sangat berkorelasi karena adanya perubahan musim, bukan karena konsumsi es krim menyebabkan kulit terbakar atau sebaliknya. Sehingga mungkin sumber daya alam yang berlimpah dan perang saudara, misalnya, berkorelasi karena variabel ketiga (katakanlah, lemahnya supremasi hukum) kedua meningkatkan risiko perang sipil dan kesulitan menghadapi negara dalam menarik investasi manufaktur (Ross 2004: 338). Ini hanya akan dapat diperiksa dengan memeriksa lebih dekat mekanisme kausal disekitar kutukan sumber daya alam.

\section{Daftar Pustaka}

Auty, R. and Gelb, A. (2001) 'The Political Economy of Resource-Abundant States', in R. Auty (ed.), Resource Abundance and Economic Development, Oxford: Oxford University Press: 126-44.

Balassa, B. (1980) The Process of Industrial Development and Alternative Development Strategies, Princeton: Princeton University.

Bannon, I. and Collier, P. (2003) 'Natural Resources and Conflict: What We Can Do', Chapter 1 in I. Bannon and P. Collier (eds), Natural Resources and Violent Conflict: Options and Actions, Washington, DC: World Bank.

Collier, P. and Hoeffler, A. (2005) 'Resource Rents, Governance, and Conflict', Journal of Conflict Resolution 49.4: 625-33.

Gelb, A. and Associates (1988) Oil Windfalls: Blessing or Curse, New York: Oxford University Press.

Higgins, B. (1968) Economic Development: Problems, Principles, and Policies, New York: WW Norton and Company.

Humphreys, M. (2005), 'Natural Resources, Conflict, and Conflict Resolution: Uncovering the Mechanisms', Journal of Conflict Resolution 49.4: 508-37.

Krueger, A. (1980) 'Trade Policy as an Input to Development', American Economic Review 70.2: 288-92. 
Ross, M. (2004) 'What Do We Know About Natural Resources and Civil War?', Journal of Peace Research 41.3: 337-56.

Ross, M. (2004) 'How Do Natural Resources Influence Civil War ? Evidence From 13 Cases', International Organisation 58.1: 35-68.

Ross, M. (2003) 'Oil, Drugs and Diamonds: The Varying Role of Natural Resources in Civil War', in K. Ballentine and J. Sherman (eds), The Political Economy of Armed Conflict: Beyond Greed and Grievance, Boulder: Lynne Reiner Publishers: 47-70.

Ross, M. (2001) 'Does Oil Hinder Democracy?', World Politics 53 (April): 297322.

Ross, M. (1999) 'The Political Economy of the Resource Curse', World Politics 51.2: $297-322$.

Rosser, Andrew (2004) 'Why did Indonesia overcome the resource curse?', IDS Working Paper No. 222. Brighton: Institute of Development Studies.

Rosser, Andrew (2006) 'The Political Economy of the Resource Curse: A Literature Survey', IDS Working Paper No.268. Brighton: The Institute of Development Studies.

Rostow, W. (1961) The Stages of Economic Growth: A Non-communist Manifesto, Cambridge: Cambridge University Press.

Sala-i-Martin, X. and Subramanian, A. (2003) Addressing the Natural Resource Curse: An Illustration from Nigeria, Washington, DC: International Monetary Fund.

Stevens, P. (2003) 'Resource Impact: A Curse or a Blessing', Draft Working Paper, Centre for Energy, Petroleum and Mineral Law and Policy, University of Dundee.

Tadjoeddin, Z.M. (2007) 'A Future Resource Curse in Indonesia: The Political Economy of Natural Resources, Conflict and Development', CRISE Working Paper No. 35. Oxford: Centre for Research on Inequality, Human Security and Ethnicity.

Wantchekon, L. (1999), Why Do Resource Dependent Countries Have Authoritarian Governments ? (12 December), New Haven, CT: Yale University. 